\title{
PENGARUH KADAR TROMBOSIT, HEMATOKRIT, HEMOGLOBIN DARAH DAN PROTEIN URIN PADA IBU PREEKLAMSI /EKLAMSI TERHADAP NILAI APGAR BAYI YANG DILAHIRKAN
}

\author{
Siti Lintang Kawuryan \\ Lab. SMF IImu Kesehatan Anak FK Unibraw/ RSU Dr Saiful Anwar Malang
}

\begin{abstract}
Preclapmsi or eclampsia is one of the risk factor for asfiksia on newborn that can predicted by lower Apgar score. The aim of this research is to know the influence of the trombocyte, hematokrit, hemoglobin, and urinary protein examination of preclampsi or eclampsi mother to baby's Apgar score. This research was a diskriptive-cross sectional retrospective study with Chi- square test, Fisher test $x 2$ for trend statistic analysis. Total sample was 100 which choosen by simple random sampling. The parameter of this study was trombocyte, hematokrit, hemoglobin, and urinary protein examination of preclampsi or eclampsi mother and baby's Apgar score. There was a significant influence relationship between the raise of blood hematocrit $(p=0,0243)$, the decrease of the blood trombocyte $(p=0,0175)$ and the high level of proteinuria $(p=0,0154)$ of preclampsi or eclampsi mother to baby's Apgar score. In the other hand, hemoglobin $(p=0,3589)$, SGOT $(p=0,5447), \operatorname{SGPT}(p=0,4850)$, Ureum $(p=0,1964)$, kreatinin $(p=0,3415)$ level was not significantly influence. The conclusion of this reseach is hematokrit $\geq 38 \%$ and urinary protein $\geq 4+$ on preclampsi or eclampsi mother are usefull for predicting lower Apgar score of the neonate with relative risk 7,609.
\end{abstract}

Keyword: preclampsi or eclampsi, trombocyte, hematokrit, hemoglobin, and urinary protein examination, Agar score

\section{PENDAHULUAN}

Angka kematian bayi sangat dipengaruhi oleh kematian perinatal. Tinggi rendahnya angka kematian perinatal tergantung pada pengawasan antenatal, pengawasan janin selama proses persalinan dan penatalaksanaan bayi baru lahir (1). Penyebab kematian bayi adalah asfiksia, Bayi Berat Lahir Rendah (BBLR) dan infeksi, dan salah satu penyebab asfiksia adalah preeklamsia/eklamsia pada ibu (2). Gangguan yang terjadi pada bayi baru lahir dari ibu yang menderita preeklamsia/eklamsia disebabkan oleh faktor-faktor plasenta, hipertensi ibu, dan obat sedativum yang diberikan pada ibu. Tergantung pada beratnya penyakit ibu, gangguan pada bayi dapat berupa kematian bayi dalam kandungan (prematuritas), gangguan oksigenasi janin secara kronis, asfiksia, renjatan IUGR (intra uterine growth retardation), depresi pernafasan atau withdrawal syndrome yang dapat terjadi akibat pemberian obat pada ibu (3). Angka kematian perinatal yang tinggi pada preeklamsia berat disebabkan oleh asfiksia, asfiksa bisa terjadi karena gangguan perfusi uteroplasenter akibat vasospasme dan kerusakan arteri spiralis (4). Asfiksia dapat dideteksi saat dalam kandungan dengan bio physical profil janin yaitu gerakan pernafasan, tonus, frekuensi, jantung, reaktifitas dan volume cairan ketuban, sedangkan untuk mengetahui derajat asfiksia nilai Apgar $(1,2,4,5)$. Menurut data statistik Angka Kematian Bayi (AKB) di Indonesia menurun dari 145 per 1000 kelahiran hidup pada tahun 1967 menjadi 57 per 1000 kelahiran hidup pada tahun 1999. pada tahun 1998 AKP menjadi 49 per 1000 kelahiran hidup, tapi terjadi peningkatan kembali menjadi 51 per 1000 kelahiran hidup. Angka ini masih menduduki tingkat tertinggi dibandingkan dengan negara-negara ASEAN lainnya (6).

Jurnal Kedokteran Brawijaya, Vol. XX, No.2, Agustus 2004.

Korespondensi: Siti Lintang K; Laboratorium/SMF IImu Kesehatan Anak FK Unibraw/RSU Dr. Saiful Anwar; Jl. Jaksa Agung Soeprapto 2, Telp.(0341) 343343, Fax.(0341) 369393

Malang-65111.email: lintangk@plasa.com
Telah diketahui pada kepustakaan memberatnya preeklamsi/eklamsi dapat dilihat dari keadaan klinik maupun hasil pemerikasaan laboratorium Pemeriksaan laboratorium tersebut adalah kadar hemoglobin, kadar hematokrit, angka trombosit, kadar SGOT darah, kadar SGPT darah, kadar kreatinin darah, kadar ureum darah, kadar protein darah dan kadar protein urin $(7,8)$.

Usaha untuk mencegah kematian perinatal akibat preeklamsia/eklamsia dapat dilakukan apabila faktor-faktor yang berhubungan dengan penyebab kematian perinatal dapat diidentifikasi (7). Salah satu penyebab kematian perinatal pada preeklamsi/ eklamsi adalah asfiksia, yang bisa diedentifikasikan dengan nilai Apgar. Oleh karenanya diduga adanya pengaruh kadar hemoglobin, hematokrit, trombosit, SGOT.SGPT, ureum, kreatinin darah dan protein urin dengan nilai Apgar.

Tujuan Penelitian untuk mengetahui apakah kadar hemoglobin, kadar hematokrit, trombosit, SGOT.SGPT, Ureum, kreatinin darah dan protein urin pada ibu preeklamsia leklamsia berpengaruh terhadap nilai Apgar bayi yang dilahirkan.

\section{METODE}

Penelitian ini merupakan penelitian diskriptif, cross sectional data diambil secara retrospektif dan diteliti untuk mengetahui pengaruh hasil pemeriksaan darah yang terdiri dari hemoglobin, hematokrit, trombosit, SGOT, SGPT, uerum, kreatinin darah dan protein urin pada ibu preeklamsi/ eklamsi terhadap nilai Apgar bayi yang dilahirkan. Alasan pemilihan jenis parameter pemeriksaan adalah bahan-bahan yang berhubungan dengan preeklamsi/ eklamsi.

Data retruspektif diambil dari paparan ibu preeklamsi/ eklamsi dan bayinya yang dirawat di RSU Dr Saiful Anwar Malang selama tahun 2003

Cara pengambilan sampel melalui simple random sampling dari catatan medik didapatkan 365 kasus preeklamsi/ eklamsi dari total kelahiran. Besar sampel yang digunakan dalam penelitian ini 100 sampel. Kriteria inklusi (Ibu dengan 
preeklamsi/eklamsi yang melahirkan di RSU. Dr. Saiful Anwar, Malang, bayi lahir tunggal tidak ada kelainan konginetal yang berat ibu tidak memiliki riwayat penyakit jantung, ginjal, diabetes melitus dan penyakit hati). Subyek penelitian dibatasi dengan kriteria tersebut diatas dengan maksud untuk mengendalikan faktor-faktor penganggu dengan membatasi kedaan ibu dan bayi. Varibel penelitian terdiri dari variabel tergantung (nilai Apgar bayi yang dilahirkan) variabel bebas (hasil pemeriksaan laboratorium ibu preeklamsi/ eklamsi, meliputi kadar hemoglobin, hematokrit, trombosit, SGOT. SGPT, ueum, kreatinin darah dan protein urine).

Diagnosa preeklamsi ditegakkan bila minimal ada 2 tanda dari: hipertensi, edema, proteinuri. Diagnosa Eklamsi ditegakkan bila ada gejala preeklamsi disertai kejang, Nilai Apgar merupakan nilai yang diperoleh dengan kriteria Apgar menit pertama yang meliputi warna kulit, frekuensi jantung, refleks atau reaksi terhadap ragsangan, tonus otot, dan pernafasan. Pengumpulan data dan analisis data: dilakukan secara kualitatif, sehingga diperoleh data dengan skala nominal dan data dengan skala ordinal:

1. Kadar hemoglobin, dengan skala nominal $(<11$ atau $\geq 11)$

2. Kadar hematokrit, dengan skala nominal $(<38$ atau $\geq 38)$

3. Hitung trombosit, dengan skala nominal $(<150.000$ atau $\geq$ 150.000)

4. SGOT dengan skala nominal $(<30$ atau $\geq 30)$

5. SGPT dengan skala nominal ( $<30$ atau $\geq 30)$

6. Ureum dengan skala nominal ( 40 atau $\geq 40$ )

7. Kreatinin dengan skala nominal $(<1$ atau $\geq 1)$

8. Protein urin , dengan skala nominal $(<2+$ atau $\geq 2+)$

9. Nilai Apgar, dengan skala ordinal $(<7$ atau $\geq 7)$

Data dikelompokkan dan dilakukan pencekalan, dianalisis statistik diskriptif yang disajikan dalam tabel frekuensi distribusi, untuk mengetahui hubungan antara hasil laboratorium dan nilai Apgar bayi digunakan metode statistik Chi- Kwadrat dan Fisher test dan $\times 2$ for trend untuk mengetahui resiko rendahnya nilai apgar dengan tingkat nilai kepercayaan minimal $95 \%$ dan dikatakan bermakna bila $p<0,05$.

\section{HASIL PENELITIAN}

Tabel 1. Distribusi sampel berdasarkan Nilai Apgar, Cara Kelahiran, tekanan darah diastole ibu, Berat badan lahir, Umur Kehamilan

\begin{tabular}{lcc}
\hline \multicolumn{1}{c}{ Variabel } & Frekuensi $(\mathbf{n}=\mathbf{1 0 0})$ & Prosentase \\
\hline $\begin{array}{l}\text { Nilai Apgar } \\
<7\end{array}$ & 27 & $27 \%$ \\
$7-10$ & 73 & $73 \%$ \\
\hline $\begin{array}{l}\text { Berat badan lahir } \\
<2500 \text { gram }\end{array}$ & 25 & $25 \%$ \\
$\geq 2500$ gram & 75 & $75 \%$ \\
Usia kehamilan & & \\
$<37$ minggu & 15 & $15 \%$ \\
$\geq 37$ minggu & 85 & $85 \%$ \\
\hline
\end{tabular}

\begin{tabular}{lcc}
\hline Tekanan darah diastole: & & \\
$<110 \mathrm{~mm} \mathrm{Hg}$ & 60 & $60 \%$ \\
$\geq 110 \mathrm{~mm} \mathrm{Hg}$ & 40 & $40 \%$ \\
\hline Cara Kelahiran & & \\
Spontan & 37 & $37 \%$ \\
Seksio Sesaria & 42 & $42 \%$ \\
Vakum Ekstraksi & 19 & $19 \%$ \\
Forsep Ekstraksi & 2 & $2 \%$ \\
\hline
\end{tabular}

Pada tabel 1 terlihat bahwa dari 100 ibu dengan preeklamsi/ eklamsi, $60 \%$ ibu dengan tensi dibawah $110 \mathrm{~mm} \mathrm{Hg}$ dan $40 \%$ dengan tensi $\geq 110 \mathrm{~mm} \mathrm{Hg}, 27(27 \%)$ bayi yang dilahirkan dengan nilai apgar rendah, $25(25 \%)$ dengan berat lahir rendah, $15(15 \%)$ lahir premature dan $10 \%$ dengan kecil masa kehamilan. Cara kehahiran terbanyak dengan bayi dengan Seksio Sesaria 42 (42\%)

Tabel 2 Hubungan antara tekanan darah, hasil laboratorium ibu, berat lahir dengan Nilai Apgar bayi yang dilahirkan

\begin{tabular}{cccc}
\hline Variabel & Nilai Apgar & Total & $p$ \\
\cline { 2 - 2 } & $<7 \quad \geq 7$ & \\
\hline
\end{tabular}

\begin{tabular}{llll}
\hline $\begin{array}{l}\text { Tekanan } \\
\text { diastole }\end{array}$ & $8(13,33 \%)$ & $52(86,8 \%)$ & $60(100 \%) \mathrm{P}=0,00016^{*}$ \\
$<110 \mathrm{~mm} \mathrm{Hg}$ & $19(47,5 \%)$ & $21(52,5 \%)$ & $40(100 \%)$ \\
$\geq 110 \mathrm{~mm} \mathrm{Hg}$ & & & \\
\hline $\begin{array}{l}\text { Berat Lahir } \\
<2500 \text { gram }\end{array}$ & $14(56 \%)$ & $11(44 \%)$ & $25(100 \%) \mathrm{P}=0,0001624$ \\
$\geq 2500$ gram & $13(17,33 \%)$ & $62(82,67 \%)$ & $75(100 \%)$ \\
\hline $\begin{array}{l}\text { Kadar } \\
\text { hemoglobin }\end{array}$ & $13(25 \%)$ & $39(75 \%)$ & $52(100 \%) \mathrm{P}=0,3588732$ \\
$<11 \mathrm{mg} / \mathrm{dl}$ & $16(33,3 \%)$ & $32(66,67 \%)$ & $48(100 \%)$
\end{tabular}

$\geq 11 \mathrm{mg} / \mathrm{dl}$

Hematokrit

$<38 \% \quad 18(22,78 \%) 61(77,22 \%) \quad 79(100 \%) \quad \mathrm{P}=0,0242698^{*}$ $\begin{array}{llll}\geq 38 \% & 10(47,62 \%) & 11(52,38 \%) & 21(100 \%)\end{array}$

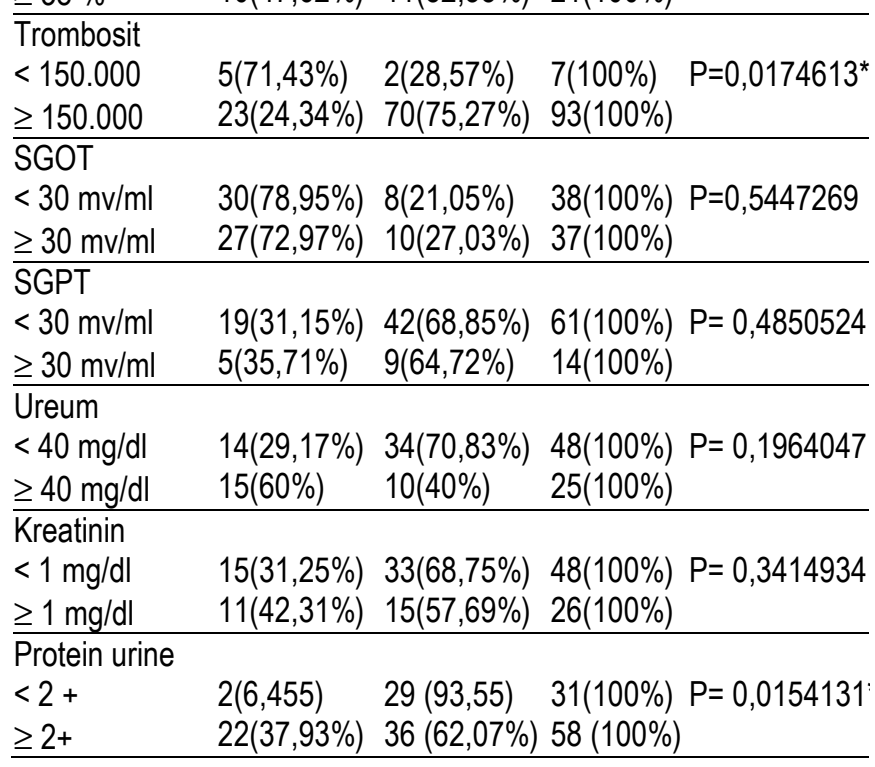

Pada tabel 2, terdapat 5 variabel yang mempunyai hubungan yang bermakna secara statistik, yaitu nilai Apgar 
dengan tekanan diastole ibu, berat lahir bayi, kadar hematokrit ibu, kadar trombosit ibu, kadar protein urin ibu $(p<0,05)$, sedangkan kadar hemoglobin, SGOT,SGPT, ureum, kreatinin tidak mempunyai pengaruh yang bermakna terhadap nilai Apgar bayi yang dilahirkan

\section{DISKUSI}

Nilai Apgar merupakan metode praktis yang secara sistematis digunakan untuk menilai keadaan umum bayi baru lahir. Jumlah nilai Apgar menunjukan respon bayi baru lahir terhadap lingkungan intrauterin dan ekstra uterin. Berdasarkan nilai Apgar dapat diketahui derajat asfiksia pada bayi.baru lahir. Nilai Apgar dipengaruhi oleh faktor ibu dan janin. Faktor janin diantaranya adalah prematuritas, hipoksia, asidosis, lilitan tali pusat, tali pusat menumbung, dan lain-lain. Sedang faktor ibu adalah kehamilan (infeksi, preeklamsia/ eklamsia, Diabetes, peyakit jantung) dan proses persalian (seksio sesaria, vakum ekstraksi, forcep ekstrasi, APB). Studi klasik oleh Nelson dan Ellenberg pada tahun 1981, bayi dengan nilai Apgar rendah mempuyai resiko kesakitan dan kematian yang besar. Nilai Apgar ini berhungan erat perubahan keseimbangan asam basa serta memberikan gambaran beratnya perubahan kardivaskuler digunakan untuk mengetahui apakah bayi menderita asfiksia atau tidak pada saat lahir $(7,8,9,10)$. Yang dinilai adalah warna kulit, frekuensi jantung, tonus otot, usaha pernafasan, dan reaksi terhadap rangsangan (8). Asfiksia dapat dideteksi saat dalam kandungan dengan ultra sound bio physical profil janin yaitu gerakan pernafasan, tonus, frekuensi, jantung, reaktifitas, volume cairan ketuban (5).

Hasil penelitian ini seperti yang terlihat pada tabel 1 terlihat bahwa dari 100 ibu dengan preeklamsi/ eklamsi, 27 (27\%) bayi yang dilahirkan dengan nilai Apgar rendah, Preeklamsi leklamsi terjadi infark pada plasenta disebabkan karena oklusi arteria spiralis, akibat dari infark placenta terhadap janin tergantung dari luas infark, serta fungsi plasenta yang masih sehat, menyebabkan gangguan oksigenasi dan nutrisi pada janin. $44 \%$ kematian perinatal karena faktor obsetri dimana $65 \%$ disebabkan karena insufisiensi plasenta. Brown menemukan bahwa kejadian asfiksia perinatal pada preeklamsi/eklamsi 4 kali lebih besar dan $40 \%$ disebabkan faktor plasenta yaitu insusifiensi, solusio plasenta, perdarahan antepartum. Pada penelitian ini didapatkan $25 \%$ dengan berat lahir rendah, $15 \%$ lahir premature dan $10 \%$ dengan kecil masa kehamilan. $42 \%$ cara kelahiran dengan bayi dengan seksio sesaria $60 \%$ ibu dengan tensi dibawah $110 \mathrm{~mm} \mathrm{Hg}$ dan $40 \%$ dengan tensi $\geq 160 \mathrm{~mm} \mathrm{Hg}$. Berat lahir rendah mempunyai hubungan yang bermakna dengan rendahnya nilai Apgar $(p=0,0001624)$ Pada preeklamsia terjadi penurunan volume plasma $30 \%-40 \%$ dari kehamilan normal, menimbulkan hemokonsentrasi dan peningkatan viskositas darah, akibatnya hipoperfusi jaringan. Sistem yang paling peka terhadap hipoperfusi adalah unit fetoplasenta, perfusi fetoplasenta menurun $35 \%-65 \%$. Sindroma pada janin timbul akibat berkurangnya perfusi uteroplasenta dan terjadi gangguan nutrisi dan respirasi. Resiko terhadap janin pada preeklamsia akibat berkurangnya sirkulasi uteroplasenta bisa menyebabkan terjadinya gangguan pertumbuhan, prematuritas $(1,3,11)$.

Hasil selanjutnya (tabel 2) tekanan diastolik ibu mempunyai pengaruh yang bermakna terhadap nilai Apgar
$(P=0,00016)$. Makin tinggi tekanan diastolik ibu makin beresiko terjadinya asfiksia secara bermakna $(p=0,00398)$. Dengan perhitungan resiko relatif didapatkan ibu dengan tekanan diastolik 100-110 mempunyai resiko 2,18 kali dan dengan daistolik $\geq 110$ $\mathrm{mm} \mathrm{Hg}$ mempunyai resiko 11,43 kali lebih besar terhadap rendahnya nilai Apgar. Peningkatan tekanan darah pada preeklamsi/eklamsi disebabkan karena penurunan kemampuan pressure natriuresis ginjal dan peningkatan resistensi perifer hal ini disebabkan karena disfugsi endothel (6). Disfungsi endotel tersebut diduga terdapatnya peningkatan TNF-a da IL -6. Disfungsi endotel dan penurunnya natriuresis ginjal akan menyebabkan berkurangnya kadar aldosteron yang akhirnya akan menurunkan volume plasma, hemokonsetrasi meningkatkan viskositas darah hal ini akan menyebabkan hipoperfusi Sindroma pada janin timbul akibat berkurangnya perfusi uteroplasenta akan terjadi gangguan nutrisi dan respirasi. Resiko terhadap janin pada preeklamsia akibat berkurangnya sirkulasi uteroplasenta selain gangguan pertumbuhan, dan prematuritas bisa terjadi hipoksemia, asfiksia janin, asidosis, menyebabkan rendahnya nilai Apgar bayi yang dilahirkan dan kematian $(1,3,12)$. Peningkatan kadar hematokrit pada preeklamsi/ eklamsi (tabel 2), juga berpengaruh secara bermaka terhadap nilai Apgar bayi yang dilahirkan $(p=0,0175)$ hal bisa disebabkan pada preeklamsi leklamsi terjadi hemokonsentrasi yang disebabkan penurunan volume plasma $(1,2)$. Makin tinggi hemokonsentrasi resiko terjadinya nilai Apgar rendah makin tinggi secara bermakna $(\mathrm{p}=0,01286)$ perhitungan resiko relatif didapatkan hematokrit 35$38 \%$ resiko relatifnya 3,2 kali sedang hematokrit > $38 \%: 7,609$ kali, hal ini berarti bahwa resiko terjadi rendahnya nilai Apgar 7,6 kali lebih besar pada ibu dengan kadar hematokrit diatas $38 \%$. Penuruan kadar hemoglobin ibu $<11 \mathrm{mg} \%$ terjadi pada $52(52 \%)$ dan $13(25 \%)$ bayi yang dilahirkan didapatkan nilai Apgar rendah, sedangkan ibu dengan kadar hemoglobin $\geq 11 \mathrm{mg} \%$, 48 (48\%), 16 $(33,3 \%)$ bayi yang dilahirkan dengan nilai Apgar rendah. Keadaan ini tidak menunjukkan perbedaan yang bermakna $(p=0,3589)$. Hal ini mungkin perubahan kadar hemoglobin saja masih belum mempengaruhi viskositas darah sehingga pengaruhnya pada sirkulasi fetoplasenta belum menyebabkan gangguan pada hipoksia janin. Penurunan kadar trombosit ibu mempunyai pengaruh yang bermakna $(p=0,01745)$, pada penelitian ini didapatkan $5(71,43 \%)$ bayi yang dilahirkan dengan nilai Apgar rendah pada ibu dengan trombosit $<150.000$, sedang pada ibu dengan kadar trombosit $\geq 150.000$, terdapat 23 ( $24,34 \%$ ) bayi yang dilahirkan dengan nilai Apgar rendah. Pada penelitian perhitungan resiko relatif tidak bisa dilakukan dikarenakan tidak ada $(n=0)$ bayi dengan nilai Apgar normal yang dilahirkan oleh ibu dengan kadar trombosit $<100.000$. Pada preeklamsi/ eklamsi terjadi nekrosis hemoragis periportal pada lobus perifer hepar yang sangat mungkin menyebabkan peningkatan enzym-enzym hati, ezym yang sering dihubungkan dengan kerusakan sel-sel hati adalah SGOT,SGPT. Pada tabel 2 terlihat 30(78,95\%) dari ibu dengan SGOT dan SGPT dibawah $30 \mathrm{mv} / \mathrm{ml}$ nilai Apgar rendah, $27(72,97 \%)$ pada ibu dengan SGOT / SGPT $\geq 30 \mathrm{~mm} / \mathrm{ml}$, $27(72,97 \%)$, hal ini menunjukkan bahwa peningkatan kadar enzym tersebut tidak menunjukkan perbedaan yang bermakna $(p=0,5447)$. Pada preeklamsi terjadi hyperkoagulasi baik pada sirkulasi maternal maupun plasental, pada keadaan ini mengakibatkan penurunan faktor kuagulasi dan trombosit. 
Trombopoiti adalah megakariosit stimulating faktor. Pada ibu dengan hipertensi menyebabkan penurunan megakariosit pada janin, menyebkan tomboitin tidak meningkat yang dapat menyebabkan trombositopeni. Dikatakan megakariosit yang rendah mempunyai resiko terjadinya asfiksia, akan tetapi mekanisme yang pasti belum diketahui (2). Hipertensi dapat menyebabkan dehidrasi intravaskuler, vasospasme sehingga terjadinya dehidrasi jaringan, yang akan menyebabkan kerusakan endotel, koagulasi / hiperkoagulasi meningkat, terjadi trombositopeni, penurunan kadar fibrinogen, terjadi perdarahan intravasculer dan DIC. Makin lamanya proses penyakit dan makin lamanya waktu antara terjadinya preeklamsi/ eklamsi dengan proses persalinan kadar trombosit makin rendah (6). Pada preeklamsi / eklamsi terjadi vasokonstriksi difus yang akan menyebabkan penurunan fungsi beberapa organ karena pendarahan dan oksigen pada organ tersebut menurun. Organ yang sering mengalami penurunan fungsi tersebut adalah unit feto-plasenter, ginjal dan otak. Gangguan fungsi ginjal berupa terjadinya penurunan perfusi dan filtrasi glomerolus, ditandai dengan peningkatan kadar ureum dan kreatinin darah. Pada penelitian ini tidak didapatkan pengaruh secara bermakna antara penigkatan kadar ureum dan kreatinin terhadap rendahnya nilai Apgar $(p=0,19640$, dan $p=0,3415)$. Terjadi albuminuri pada preeklamsi / eklamsi, merupakan akibat dari glomerulopati, sel junkta glomruler tampak membesar dan bertambah dengan pembengkaan sitoplasma, terjadi peningkatan permiabilitas terhadap protein dengan berat molekul yang besar. Pengeluaran albumin juga disertai dengan pegeluaran protein yang lain, seperti hemoglobin, globin dan transferin (3). Pada penelitian ini didapatkan hubungan bermakna antara protein urin ibu dengan nilai Apgar, yaitu 2 (s6,455\%) nilai Apgar rendah dari ibu dengan protein urin $<2+$, dibandingkan dengan $22(37,93 \%)$ nilai Apgar rendah dari ibu dengan protei urin $\geq 2+(p=0,01454)$. Makin tinggi kadar protein urin makin tinggi pula kemungkinan rendahnya nilai Apgar secara bermakna $(p=0,036)$ Perhitungan resiko relatif didapatkan protein urin $2+, 3+, 4+$, relatif resiko masing-masing 3,37 kali, 4,67 kali dan 13,13 kali lebih besar berarti makin tinggi kadar protein urin makin besar kemungkinan rendahnya nilai Apgar bayi yang dilahirkan.

\section{KESIMPULAN:}

1. Tekanan diastolik ibu dengan preeklamsi / eklamsi berpengaruh pada nilai Apgar, ibu dengan tekanan diastole $\geq$ $110 \mathrm{~mm} \mathrm{Hg}$ resiko nilai Apgar rendah 11,43 kali lebih tinggi.

2. Hematokrit, trombosit, dan protein urin ibu dengan eklamsi I preeklamsi berpegaruh pada nilai Apgar. Hematokrit $\geq 38 \%$ resiko terjadi nilai Apgar rendah 7,009 kali lebih tinggi dan Protein urin $\geq 4+$ resiko nya 13,33 kali lebih tinggi

\section{SARAN:}

1. Perlu penelitian lebih lanjut dengan subyek yang lebih besar dan dengan lebih memperhatikan variabel -variabel yang berpengaruh terhadap validitas, reabilitas data, sehingga memperkecil nilai bias yang mungkin terjadi.

2. Perlu penelitian lanjut tentang preeklamsi /eklamsi yang berhubungan dengan asfiksia dan morbiditas bayi yang dilahirkan, serta tumbuh kembangnya.

3. Perlu penelitian lanjut tentang preeklamsi /eklamsi, ultra sound bio physical profil janin yang berhubungan dengan asfiksia perinatal

4. Tensi ibu, laboratorium darah rutin dan urine dapat dipakai sebagai prediksi rendahnya nilai apgar bayi yang dilahirkan.

\section{DAFTAR KEPUSTAKAAN}

1. Killam, Allen P. The Impact of Maternal Illness in Avery Gordon B, Fletcher May Ann, Mac Donald Mhairi G. Neonatology Pathophysiology and Management of the Newborn $4^{\text {th }}$ ed. Philadelphia: JB.Lippincott Co; 19907; 188 -189.

2. Phibbs, Roderic H. Phatofisiology of Intrapartum asfiksia and resuscitation in Avery Gordon B, Fletcher May Ann, Mac Donald Mhairi G. Neonatology Pathophysiology and Management of the Newborn 4th ed. Philadelphia: JB.Lippincott Co; 248-251.

3. Cuningham FG, Mac Donal PC and Gant NF MD. Williams Obstetrics $19^{\text {th }}$ ed Norwalk: Appleton and Lange; 1993.

4. Scher Mark S. Brain Disorders of the Fetus and Neonate in Klaus Marshall H, MD. Care of the High Risk Neonate $5^{\text {th }}$ ed. Philadelphia Lodon New York St. Louis Sydney, Toronto: W.B. Saunders Co; 2001; 504-205.

5. Pinar, Halit. Patology of Pernatal and Neonatal Care in Wigglesworth Jonathan S, Singer Don B. Texbook of Fetal and Neonatal Pathology $2^{\text {nd }}$ ed. Massachusetts; Blackwell Science; 1998; 47-48.

6. Suyudi, Achmad, dr. WHO Ajak Seluruh Negara Peduli Lingkungan Sehat. 2003. (http:// www.swara. Net)

7. Salonvaara M, Rikikonen. Effect of gestational age and prenatal and perinatal event on coagulation status of premature infant; Archives of Disease in Chilhood Fetal and Neonatal Edition, 2003; 88-F319.

8. Gomella, Tricia Lacy. Periatal Asphyxia in Neoatology in Management Procedures On-Call Problems Diseases Drugs 5th ed; 1999; 512-522.

9. Stoll, Barbara J, Kligman, Robert M. Nervous System Disorers in Beehrman, Kliegman, Jenson Nelson. Texbook of Pediatrics $17^{\text {th }}$ International ed Saunder. 2002; 566- 567

10. Utsa Ihab M, Sibai Baha M. Pregnancy Induced Hyoertensionand Pre-eclampsia in Spitzer Alla R,M.D. Intesif Care of the Fetus and Neonate . Boston: Mosby St Louis; 2000; 244-248.

11. Wang J, Trudinger B. Endothelial cell dysfunction In Preeclampsia. Journal of Nephrology 19998; 11 (2): 53-56.

12. Wiswell Thomas E. Examination of the Critically III Neonate in Spitzer Alla R,MD. Intesif Care of the Fetus and Neonate. Boston: Mosby St Louis; 2000; 338-339.

13. Rushton D lan. Pathology of Placenta in Wigglesworth Jonathan S, Singer Don B. Texbook of Fetal and Neonatal Pathology $2^{\text {nd }}$ ed. Massachusetts: Blackwell Science; 1998; 168-169. 